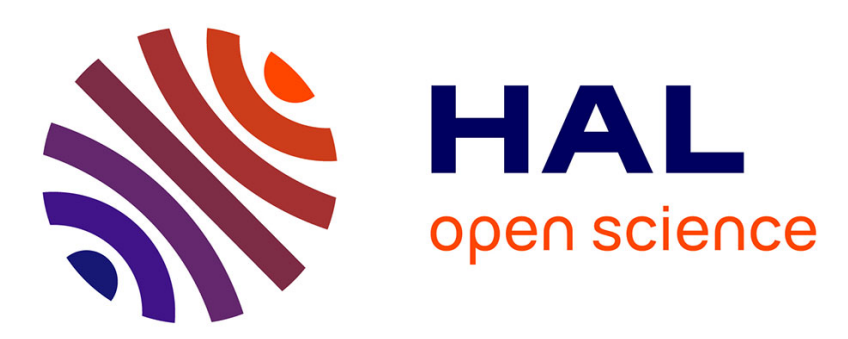

\title{
Causes of World Trade Growth in Agricultural and Food Products, 1951 - 2000: A Demand Function Approach
} Raul Serrano, Vicente Pinilla

\section{To cite this version:}

Raul Serrano, Vicente Pinilla. Causes of World Trade Growth in Agricultural and Food Products, 1951 - 2000: A Demand Function Approach. Applied Economics, 2009, 42 (27), pp.3503. 10.1080/00036840802167368 . hal-00582202

\section{HAL Id: hal-00582202 \\ https://hal.science/hal-00582202}

Submitted on 1 Apr 2011

HAL is a multi-disciplinary open access archive for the deposit and dissemination of scientific research documents, whether they are published or not. The documents may come from teaching and research institutions in France or abroad, or from public or private research centers.
L'archive ouverte pluridisciplinaire HAL, est destinée au dépôt et à la diffusion de documents scientifiques de niveau recherche, publiés ou non, émanant des établissements d'enseignement et de recherche français ou étrangers, des laboratoires publics ou privés. 


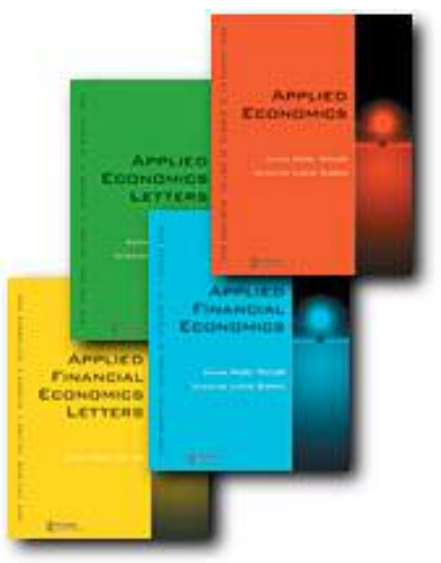

Causes of World Trade Growth in Agricultural and Food Products, 1951 2000: A Demand Function Approach

\begin{tabular}{|c|c|}
\hline Journal: & Applied Economics \\
\hline Manuscript ID: & APE-06-0762.R1 \\
\hline Journal Selection: & Applied Economics \\
\hline $\begin{array}{r}\text { Date Submitted by the } \\
\text { Author: }\end{array}$ & 18-Apr-2008 \\
\hline Complete List of Authors: & $\begin{array}{l}\text { Serrano, Raul; University of Zaragoza, Business Administration } \\
\text { Pinilla, Vicente; University of Zaragoza, Applied Economics and } \\
\text { Economic History }\end{array}$ \\
\hline JEL Code: & $\begin{array}{l}\text { F10 - General < F1 - Trade < F - International Economics, F14 - } \\
\text { Country and Industry Studies of Trade < F1 - Trade < F - } \\
\text { International Economics, N70 - General, International, or } \\
\text { Comparative }<\text { N7 - Transport, International, Domestic Trade, } \\
\text { Energy, Other Services }<\mathrm{N} \text { - Economic History, Q17 - Agriculture in } \\
\text { International Trade < Q1 - Agriculture < Q - Agricultural and } \\
\text { Natural Resource Economics }\end{array}$ \\
\hline Keywords: & International trade, Agricultural and food trade \\
\hline
\end{tabular}

\section{๑) ScholarONE" \\ Manuscript Central}




\title{
Causes of World Trade Growth in
}

\section{Agricultural and Food Products, 1951 - 2000: A Demand Function Approach}

\author{
Raúl Serrano $^{\text {a,** }}$ and Vicente Pinilla ${ }^{\mathrm{b}}$ \\ ${ }^{a}$ Department of Business Administration, University of Zaragoza, Gran Via 4, \\ 50005 Zaragoza (Spain) \\ b Department of Applied Economics and Economic History, University of \\ Zaragoza, Gran Via 4, 50005 Zaragoza (Spain)
}

Short title: Causes of World Trade Growth in Agricultural and Food Products, $1951-2000$

\begin{abstract}
The objective of the present study is to analyse the causes of the growth of international agricultural and food trade in volume terms from 1951 to 2000 . The results suggest that income growth has been the principal reason for this expansion, while exchange rate stability and the real price of agricultural products played only a minor role. Multilateral trade liberalisation and trade costs, given their long-term stability, are not elements which could have stimulated their growth. Finally, the intensive liberalisation of trade which took place in various economic regions, especially in Europe, became a key factor in promoting agricultural trade among the countries participating in regional trade agreements. The study results also indicate that the determinants of trade growth for these goods were different to those for other goods and other periods.
\end{abstract}


- Address for correspondence: Raúl Serrano. Department of Business Administration, Faculty of Economics and Business Studies. Gran Vía 4 (50005) Zaragoza (Spain). Email: raser@unizar.es 


\section{Causes of World Trade Growth in Agricultural and Food Products, 1951 - 2000: A Demand Function Approach}

\section{Introduction}

From the middle of the XIX century until the First World War a significant integration and articulation of the international economies occurred, recognised today as the first globalisation. Industrialisation, occurring principally in Europe, and ensuing income growth, accompanied by an enormous reduction in transport costs, trade liberalisation and the stable environment provided by the gold standard, are seen as its principal motors. The expansion of international trade was one of the key elements in this first globalisation, together with capital movements and overseas emigration to America. Agricultural products and food played a key role in the growth of trade, which since 1870 had accounted for approximately 50\% of such commerce. This was principally inter-industrial, in which predominated the exchange of manufactures for primary products between countries with very different specialisations. After 1914 the globalisation process experienced a short-lived halt as a result of the First World War, followed by a profound slump due to the depression of the 1930s and the Second World War (O’Rourke and Williamson, 1999).

However, in the second half of the XX century, the integration of the world economy accelerated once more. From 1945 onwards, and especially in the Western economies, a new international economic order arose, providing a stable environment in which unprecedented rates of economic growth were attained. Although at first this process was only able to recover earlier levels of integration, from approximately the early 1960s until today much greater progress has been made, to the point that frequent mention is made of a second globalisation, in which trade has once again played the leading role. Nevertheless, there exist several crucial differences between the development of international trade in each globalisation. In the second, the linchpin of international trade has been intra-industrial exchanges, predominantly between advanced countries with similar specialisations and levels of development. Trade in agricultural products and food has declined in relative importance and today represents only a very small proportion of total exchanges. The present study, in line with earlier 
research (Krugman 1995), attempts to answer the fundamental and controversial question of which factors stimulate growth in the circulation of goods and, therefore, increase international economic integration. Our study concentrates on one element of such trade, namely agricultural products and food, which experienced unprecedented growth between 1951 and 2000; it expanded not only extremely rapidly but also faster than production, and thus strongly encouraged the integration of agricultural markets, as occurred with other markets in general.

The analysis of the factors determining the growth of international trade has been the subject of much research regarding both globalisations (Estevadeordal et al. 2003; Baier and Bersgtrand 2001). However, few or none of these studies have focused on the analysis of the above-mentioned determinants over such a lengthy period for international trade in agricultural products and food ${ }^{1}$. This group, which in the early 1950s accounted for a very high percentage of international trade, has suffered a drastic reduction in its share, although it continues to be a product group which is still important for many economies, especially those of developing countries. In the second half of the XX century it has also had a peculiar significance, as a consequence of its products having been those most protected and supported by the developed countries, which has produced numerous conflicts and disputes. Our objective is therefore to typify the distinguishing features of such products in the expansion of international trade, from a long-term perspective.

Our paper estimates a demand function for agricultural and food exports on a global scale, employing cointegration methodology, which permits us to determine the factors which stimulated or curbed such exports and also the sign of their effects and their elasticities. The structure of the article is the following: firstly, following this introduction, a comparative perspective is offered of the evolution of world trade in agricultural products and food; secondly, an explanation is given of the theoretical framework of the model and of the variables employed and the data exploited for their construction; thirdly, the econometric methodology utilised is described; next, the empirical results are presented and, lastly, the principal conclusions reached are discussed.

\footnotetext{
${ }^{1}$ There is an exception, namely Coyle et al. (1998), which focuses on changes in agricultural trade composition between 1985 and 1995 .
} 


\section{International agricultural and food trade: essential data}

The second half of the XX century witnessed spectacular economic growth, particularly in the decades seen as "the golden age of capitalism" i.e. the period ranging from economic recovery following the Second World War until the onset of the international economic crisis in 1973. Per capita incomes rose worldwide until that crisis, and expansion was in fact generalised in subsequent decades, although the pattern of development varied widely. This situation was reflected in the remarkable growth of international trade. According to Maddison (2001), trade flows increased rapidly between 1950 and 1973 and, despite the slowdown between 1973 and 1988, surpassed those of all previous historical periods.

Insert Table 1: Agricultural and food trade (by volume) Average annual growth

The series we have constructed shows that agricultural and food trade grew at record levels between 1951 and 2000; it expanded at an average annual rate of $4.2 \%$ in terms of volume, much faster than the $1.4 \%$ achieved in the period 1903-1938 and the $3.7 \%$ attained in the second half of the XIX century (table 1).

Such growth is much less impressive, however, when compared to that of total world trade. Agricultural trade had been central to the first great expansion of international trade which began in the middle of the XIX century and ended with World War I, while the period from 1950 to the present witnessed a steady decline in the share of agricultural products in total trade. This process was particularly acute between 1951 and 1973, when agricultural exports fell sharply in relation to total trade, losing 17.3 percentage points in volume and 25.5 percentage points in value terms. This decline subsequently bottomed out, and the average rate of growth by volume approached that of total trade growth ${ }^{2}$.

Returning to the explanation of the growth in agricultural and food trade, two phases may be clearly distinguished in this period. The first phase, 1951-1973, saw international agricultural trade grow continuously, at an average annual rate of $5.1 \%$. Recovery after the Second World War was slow until the mid-1950s, but then rapidly accelerated in the 1960 s, to be ended in the early 1970s by the first oil crisis.

\footnotetext{
${ }^{2}$ Taking an overall view of the period, the percentage of total international trade accounted for by agricultural goods declined sharply; their share was $41.5 \%$ in 1951 but had shrunk to just $7.6 \%$ at current values by 2000 .
} 
Average annual growth in the second phase, 1973-2000, was $3.5 \%$ i.e. somewhat lower and more unstable than in the preceding years. The world economy was wracked by the energy crisis, inflation, exchange rate instability (due to the collapse of the Bretton Woods system), slower growth in the industrialised nations and a general atmosphere of uncertainty. Despite recession and instability, agricultural exports withstood the first energy crisis and grew surprisingly quickly in the second phase.

Trade grew faster than production, resulting in intense market integration; Agricultural trade exhibited the same pattern, as shown by the strong increase in the ratio of agricultural trade to agricultural output (see Chart 1). The ratio demonstrates, however, that the agricultural sector by no means achieved the pace of integration of other sectors, such as manufacturing.

Insert Chart 1: International Export Ratios of agricultural, manufactures and total trade, 19512000

\section{Theoretical background and data}

The theoretical background for our study is based on the relevant literature concerning trade, which concurs on three basic points. Firstly, the expansion of trade would seem to be historically related to income growth (Coyle et al. 1998; Irwin 2002; Estevadeordal, et al. 2003). Secondly, trade is apparently affected by factors such as market liberalisation and falling transport costs (Krugman 1995; Feenstra 1998; Baier and Bergstrand 2001); other studies (O'Rourke and Williamson 1999; Dell'Ariccia 1999; Rose 2000, Cho et al. 2002) also suggest that exchange rate volatility may have a significant impact on the evolution of trade. Among others, Frankel (1997) demonstrates that regional trade agreements (RTAs) also help to explain the evolution of exchanges. Finally, the significant changes in real prices for agricultural products may well explain variations in international exchanges.

Consequently, we have elaborated the following basic demand function for world exports of agricultural products and food between 1951 and 2000:

$$
X_{t}=f\left(G D P_{t}, N P C_{t}, \text { TRANS }_{t}, \text { PRICES }_{t}, E X C_{t}, E U 68-91, R T A 92-00\right)
$$

where $\boldsymbol{X}_{\boldsymbol{t}}$, are world exports of agricultural products and food in terms of volume (in 1995 US dollars); $\boldsymbol{G D P}$, is world GDP (in 1995 US dollars); $N \boldsymbol{P C}$, is the Nominal

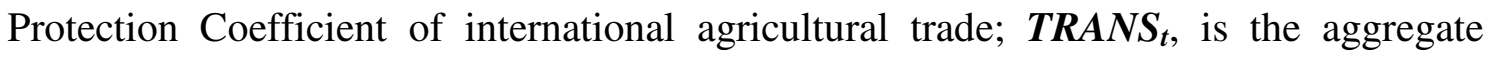




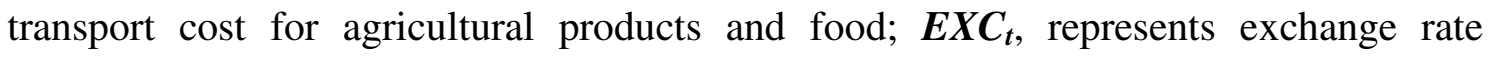
volatility; PRICES $\boldsymbol{S}_{\boldsymbol{t}}$, is an aggregate index of the prices of world agricultural exports with respect to those of total exports; $\boldsymbol{E} \boldsymbol{U}_{68-91}$ is a dummy variable which takes the value of 1 for the years 1968-1991 (to measure trade liberalisation among member countries

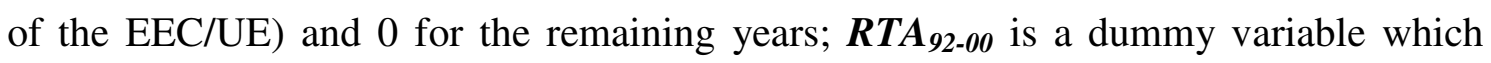
takes the value of 1 for the years 1992-2000 (to measure the impact upon agricultural and food trade of the considerable extension of RTAs to other regions) and 0 for the remaining years.

Before analysing the definition and evolution of the model's variables, we would like to emphasise that the principal difficulty we have encountered in undertaking this study is that we were able to find data series for the period for only two of the variables $(G D P, E X C)$. For the remaining variables we were forced to construct such series ourselves, an arduous task which in itself makes an important contribution to this research field, in our opinion.

Data for Agricultural and food trade $\left(\boldsymbol{X}_{\boldsymbol{t}}\right.$ ) were sourced mainly from the trade figures compiled by the Food and Agriculture Organization (FAO) of the United Nations ${ }^{3}$. These exceed the time horizons normally employed in empirical studies (they are expanded to include 1950-1960). The principal shortcoming of these data is that only a relatively small number of countries were included in the yearbooks until approximately 1960; coverage extended to most of Europe but was far from complete for the rest of the world. Consequently, we have had to make a number of estimates. Based on these sources, we have obtained a homogeneous, representative annual series for total agricultural trade at current prices. To obtain a data series for international agricultural trade by volume, we constructed price indices for the various product groups and then employed them to deflate the relevant current price series (see Note 1 in the Statistical Appendix)

The method used to construct our series constitute the principal difference between the present study and the agricultural trade series of the World Trade Organization (WTO 2003), the only one existing for the second half of the 20th century,

\footnotetext{
${ }^{3}$ These figures are available in both paper format, FAO Trade Yearbooks (FAO 1947-2000), and in electronic format, FAOSTAT database (FAOSTAT 2004)
} 
which utilises a general index of agricultural product prices to deflate the agricultural trade series in current prices ${ }^{4}$.

Insert Chart 2: Trends displayed by the variables of the model

Income $\left(\boldsymbol{G D P}_{t \cdot}\right)$ Among the various determinants of international trade, income growth and its impact upon consumption is a fundamental factor, as stated earlier. Irwin (2002), Estevadeordal et al. (2003), Baier and Bergstrand (2001), among others, have demonstrated that income is the factor with the greatest explanatory power regarding trade. In the specific case of agricultural trade, Coyle et al. (1998) have shown that income is also the principal determinant of changes in the composition of trade in agricultural products. There also exists a certain consensus that agricultural trade should be less affected by the growth of this variable, given the low income elasticity of demand for a considerable part of its constituent products ${ }^{5}$.

To study this variable, we used the world income series provided by the WTO (2003). Its evolution, as explained in the previous section, displays a strong bullish tendency, although growth decelerated after 1973.

Nominal Protection Coefficient $\left(N_{P} C_{t}\right)$ With regard to institutional factors, one of the reasons for the strong growth of international trade in the second half of the 20th century was the marked reduction in protectionism. Successive rounds of the General Agreement on Tariffs and Trade (GATT) talks reduced tariffs in many parts of the world and largely eliminated the quantitative restrictions upon non-agricultural products (Engelbrecht and Pearce, 2007) ${ }^{6}$. This significant trend towards the liberalisation of trade exchanges has been unanimously accepted as one of the principal motors of trade growth.

However, agricultural trade was excluded from the negotiations and was highly protected $^{7}$. In general, the governments of the developed countries supported and protected

\footnotetext{
${ }^{4}$ The principal advantage is that in the future we will be able to work with series disaggregated by product groups in volume, which we will have deflated with their own price indices.

${ }^{5}$ Yates (1960), Yu et al. (2002) and Cranfield et al. (2003) demonstrate the inelastic income demand of the majority of products that make up trade in agricultural products and foodstuffs, with this tending to increase as higher levels of development were achieved. For the period prior to the outbreak of the Second World War, see Pinilla and Ayuda (2008).

${ }^{6}$ For an estimation of the reduction of tariff protection, see Clemens and Williamson (2004).

${ }^{7}$ At the first round of GATT negotiations held in Geneva in 1947, pressure from the leading participants led to agriculture being excluded from the substantial reduction in tariffs and other barriers. Unfortunately, agricultural protection was largely ignored in successive GATT rounds (Annecy 1949, Turkey 1950-51,
} 
their agricultural sectors, while developing countries discriminated against theirs ${ }^{8}$, and it is reasonable to assume that this impeded faster growth in agricultural trade.

In order to measure protectionism in agricultural markets we employed the Nominal Protection Coefficient (NPC), an indicator of the degree to which domestic prices exceed border prices for the same products i.e. it measures the degree of protection resulting from the distortions produced by both sectorial and trade policies (see Note 2 in the Statistical Appendix).

The NPC, despite its simplicity, nevertheless quantifies trade barriers, both tariff and non-tariff, which are difficult to measure in the long term. However it does not reflect other factors, such as production subsidies, which also distort agricultural trade.

A second and perhaps more important deficiency, according to Tyres and Anderson (1992), is its extreme sensitiveness to fluctuations in international prices; in particular, the value of this coefficient falls significantly when prices increase rapidly. Thus, bearing in mind the considerable fluctuations in international prices during the crises of 1973 and 1979, the results supplied by this indicator must be interpreted with caution.

Turning to long-term evolution, and as Graph 2 shows and the economic literature confirms, the level of protection in agricultural markets was extremely stable in the long term, between 1951 and 2000, in contrast to the sharp decrease which occurred in the case of manufactures. The initially severe international protection of agricultural products in the 1950s was maintained and even slightly increased, through the proliferation of non-tariff barriers, especially in the $1980 \mathrm{~s}^{9}$. It must be emphasised that the decreasing protectionism reflected by the indicator following the first oil crisis appears to be more a result of falling international prices than of a reduction in protection in itself. Lastly, and as stated earlier, the agreements reached in the Uruguay Round (1986-94) progressively eliminated non-tariff barriers and reduced the levels of protection. Despite these advances, liberalisation was slight overall and only exerted a certain influence upon trade in the final five years of the period we analyse.

Geneva 1956, Dillon 1960-61, Kennedy 1964-67 and Tokyo 1974-79). Agricultural trade barriers only began to be seriously considered (and lowered) in the Uruguay Round (1986-94), as a result of political pressure from the United States and the Cairns Group, following conflicts over agricultural trade in the 1980s.

${ }^{8}$ Tyres and Anderson 1992; Lindert 1991; Diaz-Bonilla and Reca 2002; Diaz-Bonilla and Tin 2002.

${ }^{9}$ Our indicator confirms the estimates of nominal protection, which reveal record levels for the period [see also Aksoy (2005), DeRosa (2004) and Tyres and Anderson (1992)], as well as increasing non-tariff barriers in these years [see Laird and Yeats (1988) and World Bank (1995)] 


\section{Creation of Regional Trade Agreements (EU $\left.U_{68-91}, R T A_{92-00}\right)$}

Despite stable and intensive multilateral protection, this period also saw a radical liberalisation of trade via the proliferation of free trade areas, customs unions and Regional Trade Agreements (RTAs), which reduced protectionism among their signatories and thus stimulated their mutual agricultural trade ${ }^{10}$. According to Serrano (2007) and the records of the Secretariate of the World Trade Organisation (2007), this process was strengthened from the sixties onwards, when the customs union among the members of the European Economic Community was completed. It received a further boost in the nineties with the deepening of European integration and the widening of this model, by the proliferation of such agreements on an international scale ${ }^{11}$. We shall attempt to estimate the importance of this process by introducing dummy variables for the dates in which its effect upon the expansion of trade is observable, as has been done repeatedly in a significant number of recent studies ${ }^{12}$.

Transport cost $\left(\operatorname{TRANS}_{t}\right)$ Fourthly, the significant decrease in transport costs between 1850 and 1913 has been one of the principal arguments used to explain the spectacular growth of trade during the first globalisation (O'Rourke and Williamson, 1999; Mohammed and Williamson, 2004). The revolution in the means of transport and communications following the Second World War has also been offered as a partial explanation of the growth in international trade. However, it should be noted that a somewhat inconclusive debate has taken place concerning the real tendency of these $\operatorname{costs}^{13}$. On the one hand, as the recent works of Hummels (2007) and Disdier and Head (2008) have demonstrated, it would appear that during the second globalization transport costs have fluctuated in the long term, although they have not fallen as much

\footnotetext{
${ }^{10}$ Frankel 1997; Jayasinghe and Sarker 2008.

${ }^{11}$ According to Frankel (1997), the EEC customs union was finalised in 1968. This model continued to be influential in the early 1990s, when the European Union expanded and NAFTA and 33 new RTAs were established (e.g. the North American Free Trade Agreement, NAFTA, the Common Market of the South, MERCOSUR, the Andean Pact, ASEAN) and began to liberalise trade among their members. See also Sharma and Chua (1998)

12 During the last decades an extensive body of empirical studies have appeared which, using the gravity equation, have set out to analyse in the same way the effects of the proliferation of Regional Trade Agreements. See, for example, Frankel (1997), Sharma and Chua (1998) Endoh (1999, 2005), Baier and Bergstrand (2007) and, for the case of agricultural products, Cho et al. (2002), Skripnitchenko, Beladi and Koo (2006), Jayansinghe and Sarker (2007) or Sarker and Jayansinghe (2008).

${ }^{13}$ See, for example, Brun et al (2005), Huang (2007) or Duraton and Storper (2008).
} 
as was expected at the beginning. According to these authors, transport costs have remained stable and, therefore, the distance between markets continues to act as an important brake on trade.

By contrast, a number of other studies, which substitute traditional indicators of transport costs for others that measure, for example, transport time, argue that the substitution of means of transport (especially air transport), the application of new technologies applied to transport and the revolution in communications technologies have led to significant reductions in transport time, with positive effects for the bringing together of markets (see, for example, Dollar, 2004). However, while this process of drawing markets closer together has played as important role in reducing distances in the trade in manufactured goods, it does not seem to have had the same effect for the products which make up agricultural trade, given their special characteristics ${ }^{14}$.

Bearing all this in mind, and due to the difficulty of obtaining historical data for agricultural products, the present study employs a traditional indicator of transport costs. We have calculated the $\mathrm{CIF} / \mathrm{FOB}$ ratios for representative flows of bilateral agricultural and food trade (see Note 2 in the Statistical Appendix), in order to capture the proportion of the product price which the costs of transport and insurance represent.

As Graph 2 shows, such costs have not only failed to decrease, but on occasion have grown, as shown by alternative indicators of the evolution of transport costs, such as the "Liner Shipping Price Index" constructed by Hummels (1999); the long-term trend of transport costs for agricultural trade has been clearly stable.

Exchange rate volatility $\left(\boldsymbol{E X C _ { t }}\right)$ Exchange rate stability is another factor which favours the expansion of trade; instability with regard to multilateral payments (as in each of the crises of 1929, the 1970s and the 1990s) negatively affected international trade. For the period currently under analysis, several studies have shown that from 1973 onwards (following the collapse of the Bretton Woods system) increased exchange rate volatility

\footnotetext{
14 Hummels (2001) has demonstrated a small reduction in transport times for the groups of products that make up agricultural trade, whilst the categories of manufactured products (especially those involving greater complexity in the manufacturing process) have clearly benefited from significant reductions in these transport times. Other authors, such as Coyle et al. (2001), have shown only a limited impact of the reduction in transport costs for agricultural trade.
} 
reduced the level of exchanges ${ }^{15}$; there exists clear evidence that agricultural trade is especially sensitive to such instability ${ }^{16}$.

To analyse the effects of exchange rate volatility we estimated an AR(1)GARCH (1,1) model. GARCH (Generalised Autoregressive Conditional Heteroskedasticity) models permit the hypothesis of constant variance to be relaxed and that of conditional variance to be introduced i.e. the latter varies in accordance with the past information ${ }^{17}$. This option seems appropriate, given the pronounced volatility of the series. A common expression for an $\mathrm{AR}(1)-\mathrm{GARCH}(1,1)$ model is:

$$
\begin{aligned}
& d z_{t}=\delta+\phi_{1} d z_{t-1}+\zeta_{1} \\
& \sigma_{t}^{2}=\omega+\alpha \zeta_{t-1}^{2}+\beta \sigma_{t-1}^{2}
\end{aligned}
$$

where the series $d z_{t}$ is expressed as an autoregressive process with an error term which displays a conditional variance, which in turn is the dependent variable of the model on the basis of a constant i.e. volatility in the preceding period (the ARCH term), and the prediction of the conditional variance for the preceding period (the GARCH term). Consequently, the estimation of the conditional variance offers a measurement of volatility which permits its evolution to be analysed by period ${ }^{18}$.

We obtained the nominal exchange rate data from the International Financial Statistics (IFS 2006) for a basket of currencies with respect to the US dollar ${ }^{19}$, and employed them to construct an aggregate index by weighting each exchange rate for its importance in international trade in 1961.

Volatility declined throughout the 1950s, as more currencies joined the Bretton Woods system. Stability then prevailed until the end of the 1970 s, when volatility and

\footnotetext{
${ }^{15}$ Dell' Ariccia 1999; Rose 2000.

${ }^{16}$ Cho et al. (2002) prove that exchange rate volatility not only negatively affects trade in general, but also that its impact is more pronounced for homogeneous products, such as the majority of those in agricultural trade. See also a specific case in Onafowora and Owaye (2007).

${ }^{17}$ Such models, introduced by Engle (1982) and Bollerslev (1986), have been widely used in financial series.

18 This indicator of volatility (conditional standard deviation) is common in financial series and has been employed in international economics by McKenzei (1999) for exchange rates.

${ }^{19}$ The currencies of 16 countries were matched against the US dollar: Australia, Germany, Belgium, Canada, China/Hong Kong, Egypt, France, Greece, India, Italy, Japan, Portugal, Spain and the United Kingdom.
} 
exchange rate risks reappeared and were only moderated by the emergence of systems which facilitated exchanges, such as the European Monetary System (EMS) ${ }^{20}$.

Real prices of agricultural and food products $\left(\right.$ PRICES $\left._{t}\right)$ The last but not least of the factors considered is the relative evolution of agricultural prices ${ }^{21}$. These increased at an average annual rate of $1.8 \%$ between 1951 and 2000, far behind the increases in total international trade prices (2.8\%). As Graph 2 shows, real prices of agricultural exports fell sharply in the second half of the 20th century, which presumably encouraged their growth.

We may distinguish two stages in the evolution of the prices of agricultural trade products: the period 1951-1973 was basically stable, with price trends similar to those for international trade in general; the second, 1973-2000, saw pronounced fluctuations as well as important divergences with regard to the general price index of international trade. The latter period witnessed a greater relative decrease in agricultural trade prices, particularly during the energy crises of 1973 and $1979^{22}$.

\section{Econometric model}

To analyse the determinants of growth in agricultural products and food we convert into logarithms the variables of the model described in the previous section.

To avoid the problem of spurious regressions, we analyse the order of integration of the data series; having studied their graphs, correlograms and partial correlograms and the augmented Dickey-Fuller statistic (Table 2) (Dickey-Fuller 1981), we conclude that the $X, G D P, P R I C E S$ and EXC variables are integrated of order one I(1) and that the NPC and TRANS variables are stationary. As the majority of these variables are integrated of order one, we test them for possible cointegration.

Insert Table 2: Dickey-Fuller tests

To analyse the potential cointegration among the variables we use the EngleGranger test (Engle-Granger 1987) and the CRDW test based on the Durbin-Watson test for regression. We perform these tests for the four variables which were $I(1)$; their

\footnotetext{
${ }^{20}$ Rose (2000) shows that common currencies, by reducing volatility among participants, positively affect total trade.

${ }^{21}$ Note 1 in the Statistical Appendix explains how we have been able to construct the aggregate index of the real price evolution of agricultural products.

${ }^{22}$ As Diakosavvas and Scandizzo (1991) and Ocampo and Parra (2003) also show.
} 
results show that these variables and the dummy variables $E U_{68-91}$ and $R T A_{92-00}$ would be cointegrated, according to the Engle-Granger test.

Since the majority of the variables we analyse are integrated of the same order and, unsure whether the variables are cointegrated, we follow Kremers et al. (1992) and propose a series of Error Correction Mechanism (ECM) models. These have two parts, one of which reflects the short-term relationship between the variables (expressed in differences), while the other describes the long-term equilibrium relationship. If the sign of the ECM $(\alpha)$ term is negative and significant we can conclude that the variables in the second part of the model are cointegrated. These models have also taken into account in the short term the variables which, when analysing their integration, we concluded were stationary and cannot therefore be included in the long-term equilibrium relationship, and a set of dummy variables, in order to measure the effect of certain factors upon trade behaviour.

Insert Table 3: Engle-Granger and CRDW tests

Thus, the model we have selected, utilising econometric model selection criteria (such as Akaike's AIC and the SBIC developed by Schwarz), is as follows:

$$
\begin{aligned}
& \log \Delta X_{t}=\beta_{1} R T A_{92-00}+\beta_{2} E U_{68-91}+\beta_{3} \log \Delta X_{t-1}+\beta_{4} \log \Delta G D P_{t-1}+ \\
& \beta_{5} \log \Delta P R I C E S_{t-1}+\beta_{6} \log \Delta G D P_{t}+\beta_{7} \log N P C_{t}+\beta_{8} \log N P C_{t} * E U_{68-91}+ \\
& \beta_{9} \Delta E X C-\alpha\left(X_{t-1}-\beta_{10} G D P_{t-1}-\beta_{11} P_{\left.R I C E S_{t-1}-\beta_{12} E X C_{t-1}\right)+u_{t}}\right.
\end{aligned}
$$

The variables TRANS and PRICES do not appear in the short term as they are not significant at the 5\% level. Employing the criteria which test the hypothesis of homoskedasticity (WHITE), non-autocorrelation (LM(i)) and normality (J-B), the models are spherical. In order to test whether the introduction of the dummies affects the robustness of the long-term estimations of the elasticities, we also present a model which excludes them.

In Table 4 we present both estimations. Estimation (1) is the model without dummies and estimation (2) is the model we have selected.

In model (2) all the variables were significant at 5\%. The negative sign and the significance of the ECM term led us to conclude that the variables in the second part of the model are cointegrated. Model (2) also allows us to estimate the short-run and longrun elasticities of the trade variable with regard to the independent variables.

Insert Table 4: Non-linear least squares estimates of the trade function 
Insert Table 5: Short-run and long-run elasticities

\section{Estimation results}

The model's results confirm that world income is the fundamental variable in explaining the growth of world trade in agricultural products and food during the second half of the 20th century. The variable is significant at 5\% and displays the expected sign, although its elasticity is predictably low (approximately unity), which is logical given the type of products in question. These results are unsurprising and confirm, for the case of agricultural trade, the fundamental role of this variable in explaining its expansion, as other studies have demonstrated for the case of trade in general.

With regard to exchange rate volatility, the results from our model clearly show that this variable helps to explain the growth of agricultural trade, being significant at 5\%; this supports the findings of other authors, such as Dell'Ariccia (1999) and, specifically for agricultural trade, Cho et al. (2002). Its negative sign indicates that increased volatility negatively affected agricultural and food trade; nevertheless, its extremely low elasticity confirms its relatively minor importance, as Rose (2000) also argues. Thus, the increasing stability of exchange rates from the 1950s until the crisis of the 1970s favoured the growth of agricultural trade, while their pronounced instability until the early 1980 s tended to slow it down. Lastly, the renewed trend towards greater stability in the last two decades encouraged the expansion of such trade.

Moreover, agricultural prices are also significant at 5\% and thus favoured the expansion of trade, as their negative sign demonstrates. Given their relatively low elasticity, however, these were not a key factor. Their almost permanent downward trend, since the early 1950s, thus produced a slight boost in the agricultural trade growth, particularly after 1973 when the acceleration in price falls encouraged producer countries to increase their exports, as a way of maintaining their revenue.

Our results underline the importance for agricultural trade growth of the liberalisation which has taken place within the RTAs created, and especially of the EEC/EU ${ }^{23}$. The explanatory power of the model which includes the dummy variables introduced to this end is notably higher than that of the model excluding them. Where

${ }^{23}$ As Baier and Bergstrand (2007) have shown for total trade. 
agricultural trade liberalisation occurred (for example, in countries with RTAs), its effects were positive. Both the dummy variable $E U_{68-91}$ and the more general $R T A_{92-00}$ are significant at $5 \%$ in explaining agricultural trade expansion and, moreover, display the positive sign expected. Nevertheless, if we compare the two coefficients, it is clear that the reduction of trade barriers produced by the creation and development of the EEC/EU was much more important.

Thus, the proliferation of RTAs was positive in aggregate terms for agricultural trade. However, the net increase in international agricultural trade resulting from the creation and expansion of RTAs has had very different implications for distinct groups of countries. A significant expansion of trade has resulted for RTA signatories, with the creation of trade resulting from the increase in exchanges within the EEC/EU being especially notable. ${ }^{24}$ By contrast, the new regionalism of the nineties had less impact on the trade between the countries involved.

Finally, it is also clear that the evolution of transport costs and protectionism (two factors commonly used to explain trade growth) do not significantly influence the growth in the exchanges of agricultural products and food. The stationarity of both series means there exists no long-term relationship with the development of agricultural and food trade. Such stationarity implies that in the long term these variables tend to remain at levels very similar to their initial figures. Nevertheless, the stability of these two variables may indicate a restriction upon potential growth, especially when compared to that of other goods such as manufactures. As Baier and Bergstrand (2001) show, the greater relative growth of overall trade in the period 1958-1988, is largely explained by progressive market liberalisation.

The contrast with other historical periods in which exchanges were intensified is also interesting. Estevadeordal et al. (2003) show that both the transport revolution and trade liberalisation played key roles in the growth of trade between 1870 and 1913. Agricultural trade (which accounted for $50 \%$ of total trade) benefited from the reduction of trade barriers and falling transport costs which affected all types of products. What might have occurred if the liberalisation of trade for agricultural products and food had equalled that for manufactures is a question that remains unanswered ${ }^{25}$.

\footnotetext{
${ }^{24}$ This result is consistent with those reported in other works, such as Sarker and Jayasinghe (2007), Serrano (2007) and Serrano and Pinilla (2007).

${ }^{25}$ The difficulties in constructing a variable to measure the evolution of agricultural protection on an international scale plays down our results, since a shadow of doubt is cast upon their accuracy by the marked sensitivity of the nominal protection coefficient to variations in international prices.
} 


\section{Concluding remarks}

This study is a contribution to the empirical literature on the factors behind the development of world trade. Its principal strength is its focus on the determinants of the evolution of trade in agricultural products and food, the pattern of which differs from that of other products and is evident if we take into account its marked reduction relative to total trade in the second half of the 20th century. We also consider that our research helps to clarify the evolution of agricultural and food trade over an extended period, exceeding the time horizons normally employed in empirical studies; furthermore, we believe that the reconstruction of certain variables to undertake the study from such a long time perspective is in itself valuable, as this supplies information regarding trade evolution and contributes to the understanding of the behaviour of some of the principal determinants of agricultural and food trade.

Our results show that increased world income has been the principal influence upon the growth of agricultural trade, while price changes in agricultural products and exchange rate volatility are also significant variables, although less important. Furthermore, in order to explain trade in agricultural and food products in the second half of the XX century, it is essential to take into account the important effect of the partial liberalisation occurring in various economic regions, especially the EEC/EU.

Two important conclusions can be extracted from these results. Firstly, while our results are not surprising, they do emphasise the singularity of agricultural products and food compared to manufactures and, consequently, the distinct importance identical variables may possess in explaining the behaviour of different products. This occurs, as we have seen, with the two principal barriers to trade, namely distance and the level of protectionism, which have affected the two product types very differently. The stability of transport costs and protectionism for agricultural products and food is in sharp contrast to their reduction for manufactures and, therefore, their significant influence upon trade growth. In the case of agricultural trade, we believe that potential growth has been restricted by high levels of protectionism and the inability to exploit advances in transport times and means. Furthermore, if income is the principal factor explaining trade, agricultural products have an income elasticity far removed from that of manufactures and, from this perspective, fewer possibilities for trade to increase. The 
above factors are important variables when trying to explain the heavy loss of share of agricultural products in international markets.

Nevertheless, this loss of market share, or declining dynamism in comparative terms, must also be analysed in the context of the profound changes international trade underwent during the two globalisations. Our results assist the comprehension of the change in trade patterns during the second half of the 20th century; in the so-called first globalisation, complementarity between industrial and agro-exporting economies was predominant, but gradually declined following the Second World $\mathrm{War}^{26}$.

Lower demographic growth in the developed countries, accompanied by an extremely high level of per capita income and the technical possibilities of replacing natural raw materials by synthetic products, resulted in reduced demand for agricultural products and food. In addition, the spectacular increase in agricultural productivity, based principally on increased total factor productivity (TFP), due to technological changes associated with the green revolution, dramatically changed the potential of the advanced countries to increase their productive capacity with regard to food and agricultural raw materials ${ }^{27}$.

As a result, the regions most dependent upon income from agricultural trade (Africa, Asia and Latin America) saw their relative share decline in favour of the more developed countries. Our results provide two explanations: on the one hand, agricultural markets were subject to continuously severe protection; on the other, intensive trade liberalisation occurred, but only within certain economic regions. In particular, EEC/EU member states, with a protected and government-supported agriculture and an increasingly liberalised internal market, not only achieved the self-sufficiency which they had advocated in the difficult postwar years but also became the principal promoters of agricultural exchanges.

However, variations in the prevailing pattern of agricultural trade were also closely related to changes in its composition. Following the Second World War, rapid income growth, increasing urbanisation, improved transportation, changing lifestyles and marketing altered consumption patterns, substituting high value added processed foods for traditional foodstuffs (Rae and Josling 2003).

\footnotetext{
${ }^{26}$ Aparicio et al (2008).

${ }^{27}$ Federico (2005) demonstrates its strong growth by providing various estimations of the Total Factor Productivity of agriculture in developed countries.
} 


\section{Acknowledgments}

This study has received financial support from the Ministry of Education and Science of the Spanish Government, project SEJ 2005-077556. The final version has benefited from the comments of participants in the Sixth European Historical Economics Society Conference (Istanbul, 2005) and in seminars held in the Universities of Zaragoza (Spain) and the Republic (Uruguay). The collaboration of María-Isabel Ayuda in the econometric analysis has been crucial. We also wish to thank Lorea Barrón, María Dolores Gadea, Domingo Gallego, Eva Pardos and Javier Silvestre for their comments.

\section{References}

Aparicio, G. (2000) El comercio internacional de alimentos y materias primas agrícolas entre 1900 y 1938. Unpublished Ph. D. dissertation, University of Zaragoza.

Aparicio, G., Pinilla, V., and Serrano, R. (2008) Europe and the international trade in agricultural and food products, 1870-2000, in Agriculture and Economic Development in Europe since 1870 (Eds.) P. Lains, and V. Pinilla, Routledge, London.

Askoy, M. (2005) Global agricultural trade policies, in Global agricultural trade and developing countries, M. Askoy, and J. Beghin, World Bank, Washington DC.

Baier, S. and Bergstrand, J. (2001) The growth of world trade: tariffs, transport costs, and income similarity, Journal of International Economics, 53, pp 1-27.

Baier, S.L., and, Bergstrand, J.H. (2007) Do free trade agreements actually increase member's international trade?, Journal of International Economics, 71, 72-95

Berkun, S. and Mejil, H. (2000) The application of trade and growth theories to agriculture: a survey, The Australian Journal of Agricultural and Resource Economics, 44, 505542.

Bollerslev, T. (1986) Generalized autoregressive conditional heteroskedasticity, Journal of Econometrics, 31, 307-327.

Brülhart, M. and Elliott, R. (1998) Adjustment to the European single market: inferences from intra-industry trade patterns, Journal of Economic Studies, 25 (3), 225-247. 
Brun, J.F., Carrère, J., and Guillaumont, P. (2005) Has Distance Died? Evidence from a Panel Gravity Model, World Bank Economic Review, 19(1), 99-120

Cho, G.; Sheldon, I. and McCorriston, S. (2002) Exchange rate uncertainty and agricultural trade, American Journal of Agricultural Economics 84 (4), 931-942.

Clemens, M.A. and Williamson, J.G. (2004) Why did the tariff-growth correlation change after 1950? Journal of Economic Growth 9, 5-46.

Coyle, W., Hall, W., and Ballenger, N. (2001) Transportation technology and the rising share of U.S. perishable food trade, in The changing structure of global food consumption and trade, Agriculture and Trade Report, WRS-01-1, Economic Research Service/U.S. Department of Agriculture, Washington.

Coyle, W.; Gehlhar, M.; Hertel, T.; Wang, Z. and Yu, W. (1998) Understanding the Determinants of Structural Change in World Food Markets, American Journal of Agricultural Economics, 80 (5), 1051-1061.

Crafts, N. and Venables, A. (2003) Globalization in History: A Geographical Perspective, in Globalization in Historical Perspective (Eds.) M. Bordo; A. Taylor, and J. Williamson, University of Chicago Press, Chicago, 323-364.

Cranfield, J., Eales, J., Hertel, T. and Preckel, P. (2003) Model selection when estimating and predicting consumer demands using international cross section data, Empirical Economics, 28, 353-364.

Dell'Ariccia, G. (1999) Exchange rate fluctuations and trade flows: evidence from the European Union, IMF Staff Papers , 46(3), 315-334.

Derosa, D. (2004) Modeling the effects on agriculture of protection in developing countries. in Agriculture and the New Trade Agenda, (Eds.) M. D. Ingco and L. A. Winters, Cambridge University Press, World Bank.

Diakosavvas, D. and Scandizzo, P. (1991) Trends in the Terms of Trade of Primary Commodities, 1990-1982: The Controversy and its Origins, Economic Development and Cultural Change, 39 (2), 231-264.

Díaz-Bonilla, E. and Reca, L. (2002) Trade and agroindustrialization in developing countries: trends and policy impacts, Agricultural Economics, 23, 219-229. 
Diaz-Bonilla, E. and Tin, J. (2002) That was then but this is now: multifunctionality in industry and agriculture, TMD Discussion paper, 94,International Food Policy Research Institute (IFPRI) Trade and Macroeconomics Division, Washington.

Dickey, D.A. and Fuller, W.A. (1981) Likelihood ratio tests for autoregressive time series with a unit root, Econometrica, 49, 1057-1072.

Disdier A.C., and, Head, K. (2008) The Puzzling Persistence of the Distance Effecct on Bilateral Trade, Review of Economics and Statistics, 90(1), 37-41

Duranton, G., and, Storper, M. (2008) Rising Trade Costs? Agglomeration and Trade with Endogenous Transaction Costs, Canadian Journal of Economics, (Forthcoming)

Endoh, M., (1999) Trade creation and trade diversion in the EEC, the LAFTA and the CMEA: 1960-1994, Applied Economics, 31 (2), 207 - 216.

Endoh, M., (2005) The effects of the GSTP on trade flow: mission accomplished?, Applied Economics, 37, 487 - 496.

Engelbrecht, H-J., and, Pearce, C. (2007) The GATT/WTO has promoted trade, but only in capital-intensive commodities!, Applied Economics, 39(12), 1573-1581

Engle, R. F. (1982) Autoregressive Conditional Heteroskedasticity with Estimates of the Variance of U.K. Inflation, Econometrica, 50, 987-1008.

Engle, R. F. and Granger, C.W.J. (1987) Cointegration and error-correction: representation, estimation and testing, Econometrica, 55, 251-276.

Engle. R. F. and Yoo, B. S. (1987) Forecasting and testing in cointegrated systems. Journal of Econometrics, 35, 143-159.

Estevadeordal, A.; Frantz, B. and Taylor, A.M. (2003) The Rise and Fall of World Trade, 1870-1939, Quarterly Journal of Economics, CXVIII (2), 359-407.

FAO (1947-2000) Trade Yearbook FAO, Food and Agricultural Organization of the United Nations (FAO), Rome.

FAOSTAT (2004) FAOSTAT-Agriculture Database, FAO, Rome, (http://faostat.fao.org/faostat/collections?subset=agriculture\&language=ES)

Federico, G. (2005) Feeding the World. An Economic History of Agriculture, 1800-2000, Princeton University Press, Princeton. 
Feenstra, R. (1998) Integration of trade and disintegration of production in the global economy, Journal of Economic Perspectives, 12 (4), 31-50.

Field, M. and Pagoulatos, E. (1998) Foreign trade elasticities and import discipline, Applied Economics, 30 (1), 105 - 111.

Frankel, J. (1997) Regional trading blocs in the world economic system, Institute for International Economics, Washington.

Gruber, H.G. and Lloyd, P.J. (1975) Intra-industry trade, Macmillan, London.

Huang, R.R., (2007) Projecting World Food Demand Using Alternative Demand Systems, European Economic Review, 51(1), 161-181

Hummels, D. (1999) Have international transportation costs declined? Working Paper Graduate School of Business, University of Chicago.

Hummels, D. (2001) Time as a barrier, Working paper Purdue University.

Hummels, D. (2007) Transportation Costs and International Trade in the Second Era of Globalization, Journal of Economic Perspectives, 21 (3) 131-154

IFS (2006) International Financial Statistics, Online Service, International Monetary Fund. Washington, (http://ifs.apdi.net/imf/logon.aspx)

Irwin, D.A. (2002) Long-run trends in world trade and income. World Trade Review, 1(1), 89-100.

Jayasinghe, S. and Sarker, R. (2008) Effects of Regional Trade Agreements on Trade in Agrifood Products: Evidence from Gravity Modeling Using Disaggregated Data, Review of Agricultural Economics, 30 (1), 61-81.

Kremer, J.J.M., Ericsson, N.R. and Dolado, J. (1992) The Power of Cointegration Tests, Oxford Bulletin of Economics and Statistics, 54, 325-348.

Krugman, P. (1995) Growing World Trade: Causes and Consequences, Brookings Papers on Economic Activity, 1, 327-377.

Laird, S. and Yeats, S. (1988) Trends in nontariff barriers of developed countries, 19661986, Working Papers in International Trade, World Bank.

Lewis, A. W. (1981) The Rate of Growth of World Trade, 1830-1973, in The World Economic Order (Eds.) L.S. Grassman and E. Lundberg, Macmillan, London. 
Lindert, P. (1991) Historical Patterns of Agricultural Policy, in Agriculture and the State. Growth, Employment, and Poverty in Developing Countries P.C. Timmer (Ed.), Cornell University Press, Ithaca, pp. 1-29.

Maddison, A. (2001) The world economy: a millennial perspective, OECD, Paris.

McKenzei, M.D. (1999) The impact of exchange rate volatility on international trade flows, Journal of Economic Surveys, 13 (1), 71-106.

Mohammed, S. S. I.. and Williamson, J. G. (2004) Freight Rates and Productivity Gains in British Tramp Shipping 1869-1950, Explorations in Economic History, 41, 172203.

O'Rourke, K.H. and Williamson, J. G. (1999) Globalization and History. The Evolution of a Nineteenth-Century Atlantic Economy, The MIT Press, Cambridge, MA.

Ocampo, J.A. and Parra, M.A. (2003) The terms of trade for commodities in the twentieth century, CEPAL Review , 79, 7-35

Onafowora, O.A., and, Owoye, O. (2007) Exchange rate volatility and export growth in Nigeria, Applied Economics, DOI: 10.1080/00036840600827676.

Pinilla, V. and Ayuda, M.I. (2008) Market dynamism and international trade: a case study of Mediterranean agricultural products, 1850-1935, Applied Economics, 40 (5), 583-595.

Rae, A. and Josling, T. (2003) Processed food trade and developing countries: protection and trade liberalization, Food Policy, 28 (2), 147-166.

Rose, A. (2000) One Money, One Market: Estimating the Effect of Common Currencies on Trade, Economic Policy, 30, 7-45.

Sargan, I.D. and Bhargava, A. (1983) Testing Residuals from Least Squares Regressions Analysis, Econometrica, 51, 153-174.

Sarker, R., and, Jayasinghe, S. (2002) Regional trade agreements and trade in agri-food products: evidence for the European Union from gravity modelling using disaggregated data, Agricultural Economics, 37, 93-104

Serrano, R. (2007) Ensayos sobre el comercio internacional de productos agrarios y alimentos, 1951-2000. Unpublished Ph. D. dissertation, University of Zaragoza. 
Serrano, R. and V. Pinilla (2007) Agricultural and food trade in European Union countries, 1962-2000: a gravity ecuation approach using disagregatted data, Seventh Conference of the European Historical Economics Society, Lund $29^{\text {th }}$ June- $1^{\text {st }}$ July.

Sharma, S.C. and S.Y. Chua (1998) ASEAN: economic integration and intra-regional trade, Applied Economics Letters, 7(3), 165-169.

Skripnitchenko, A., Beladi, H., and, Koo, W.W. (2006) Preferential Trade Arrangements: Impacts on Agricultural Trade and Income, Review of Agricultural Economics, 28(3), 408-415

Tyres, R. and Anderson, K. (1992) Disarray in World Food Markets: A Quantitative Assessment, Cambridge University Press, Hong Kong.

UN COMTRADE (2003) UN Commodity Trade Statistics Database, Statistical Division of the United Nations, New York, (www.un.org //unstats.un.org/unsd/comtrade)

United Nations (1987) Métodos utilizados por las Naciones Unidas para construir Índices de Precios del Comercio Internacional, Volumen I, Informes Estadísticos serie M, 82 (1)m United Nations, New York.

World Bank (1995) Agricultural trade liberalization in the Uruguay Round, The World Bank, Washington.

World Bank (2004) World development Indicators, World Bank, Washington.

World Trade Organization (2003) Selected long-term trends, International Trade Statistic, World Trade Organization, Geneva, (http://www.wto.org/spanish/res_s/statis_s/its2003_s/its03_longterm_s.htm)

World Trade Organization (2007) Evolution of Regional Trade Agreements in the World, 1948-2007, Regional Trade Agreements: Facts and figures, WTO Secretariat (http://www.wto.org/english/tratop_e/region_e/regfac_e.htm)

Yates, P. L. (1960) Food, Land, and Manpower in Western Europe, Macmillan \& Coltd, New York.

Yu, W., Hertel, T., Preckel, P., and, Eales, J. (2002) Projecting World Food Demand Using Alternative Demand Systems, Economic Modelling, 21, 99-129 


\section{Tables}

Table 1: Agricultural and food trade (by volume): average annual growth

$\begin{array}{ll}1850-1902 & 3.7 \\ 1903-1938 & 1.4 \\ 1951-2000 & 4.2 \\ 1951-1973 & 5.1 \\ 1974-2000 & 3.5\end{array}$

Source: 1850-1902 Lewis (1981); 1903-1938 Aparicio (2000); 1951-2000 authors' calculations, based on FAO (19472000), FAOSTAT (2004), UN Comtrade (2003), and WTO (2003), see Statistical Appendix. The data for 1850-1902 are all for primary products and include non-agricultural commodities.

Table 2: Dickey-Fuller tests

\begin{tabular}{cccc}
\hline VARIABLES & I(1) versus I $(\mathbf{0})$ & $\mathbf{I}(\mathbf{2}) \operatorname{versus} \mathbf{I}(\mathbf{1})$ & \\
\hline$X$ & -2.00 & -6.16 & $\mathrm{I}(1)$ \\
GDP & $(0.59)$ & $(0.00)$ & $\mathrm{I}(1)$ \\
& -0.28 & -6.62 & \\
NPC & $(0.99)$ & $(0.00)$ & $\mathrm{I}(0)$ \\
& -4.11 & -7.71 & $\mathrm{I}(0)$ \\
TRANS & $(0.01)$ & $(0.00)$ & $\mathrm{I}(1)$ \\
& -4.37 & -9.44 & $(0.00)$ \\
& $(0.005)$ & -2.50 & $\mathrm{I}(1)$ \\
& -2.31 & $(0.01)$ &
\end{tabular}

(p-values in brackets)

Table 3: Engle-Granger and CRDW tests

\begin{tabular}{ccc}
\hline VARIABLES & E-G & CRDW \\
\hline$X, G D P, P R I C E S, E X C$ & -3.08 & 0.47 \\
$X, G D P, P R I C E S, E X C, E U_{68-91,}$ RTA $_{92-00}$ & $(-4.35)$ & $(1.05)$ \\
& -4.8 & 0.97
\end{tabular}

(Critical points in brackets, from Sargan and Barghava (1983) for the CRDW test and from Engle and Yoo for the E-G test (1987) 
Table 4: Non-linear least squares estimates of the trade function

\begin{tabular}{|c|c|c|}
\hline & \multicolumn{2}{|c|}{ VARIABLES ESTIMATIONS } \\
\hline & (1) & (2) \\
\hline$R T A_{92-00}$ & & $\begin{array}{l}0.05 \\
(3.39)\end{array}$ \\
\hline$E U_{68-91}$ & & $\begin{array}{l}0.81 \\
(2.29)\end{array}$ \\
\hline$\Delta X_{t-1}$ & $\begin{array}{l}0.32 \\
(2.53)\end{array}$ & $\begin{array}{l}0.36 \\
(4.85)\end{array}$ \\
\hline$\Delta G D P_{t-1}$ & $\begin{array}{l}-1.25 \\
(-3.99)\end{array}$ & $\begin{array}{l}-0.79 \\
(-4.16)\end{array}$ \\
\hline$\triangle P R I C E S_{t-1}$ & $\begin{array}{l}0.32 \\
(3.08)\end{array}$ & $\begin{array}{l}0.28 \\
(4.61)\end{array}$ \\
\hline$\Delta G D P_{t}$ & $\begin{array}{l}0.70 \\
(2.69)\end{array}$ & $\begin{array}{l}0.98 \\
(6.19)\end{array}$ \\
\hline$N P C_{t}$ & $\begin{array}{l}0.15 \\
(2.92)\end{array}$ & $\begin{array}{l}0.34 \\
(7.40)\end{array}$ \\
\hline$N P C_{t} * E U_{68-91}$ & & $\begin{array}{l}-0.19 \\
(-2.48)\end{array}$ \\
\hline$\Delta E X C_{t}$ & $\begin{array}{r}-0.04 \\
(-1.69)\end{array}$ & $\begin{array}{l}-0.06 \\
(-4.37)\end{array}$ \\
\hline E.C.M. $(\alpha)$ & $\begin{array}{l}-0.35 \\
(-4.28)\end{array}$ & $\begin{array}{l}-0.98 \\
(-11.09)\end{array}$ \\
\hline$G D P_{t-1}$ & $\begin{array}{l}1.03 \\
(31.65)\end{array}$ & $\begin{array}{l}1.05 \\
(69.22)\end{array}$ \\
\hline PRICES $_{t-1}$ & $\begin{array}{l}-0.33 \\
(-2.76)\end{array}$ & $\begin{array}{l}-0.33 \\
(-12.03)\end{array}$ \\
\hline$E X C_{t-1}$ & $\begin{array}{c}-0.13 \\
(-3.50)\end{array}$ & $\begin{array}{l}-0.11 \\
(-13.50)\end{array}$ \\
\hline$R^{2}$ & 0.52 & 0.85 \\
\hline $\bar{R}^{2}$ & 0.41 & 0.80 \\
\hline $\mathrm{LM}(1)$ & $0.19[0.66]$ & $3.25[0.07]$ \\
\hline $\operatorname{LM}(2)$ & $2.02[0.36]$ & $5.7[0.06]$ \\
\hline $\operatorname{LM}(3)$ & $3.39[0.33]$ & $5.72[0.13]$ \\
\hline $\mathrm{LM}(4)$ & $3.87[0.40]$ & $8.30[0.08]$ \\
\hline WHITE & $26.66[0.14]$ & $27.48[0.19]$ \\
\hline $\mathrm{J}-\mathrm{B}$ & $0.67[0.72]$ & $1.22[0.548]$ \\
\hline
\end{tabular}

Table 5: Short-run and long-run elasticities

\begin{tabular}{ccc} 
& Short-run elasticities & Long-run elasticities \\
\hline GDP & 0.98 & 1.05 \\
NPC & 0.34 & -- \\
& $0.15(1969-1991)$ & -0.33 \\
PRICES & --- & -0.11 \\
EXC & -0.06 & \\
\hline
\end{tabular}

(p-values in brackets) 
TABLE 6: Indices of agricultural and food trade, income, protection, transport costs, exchange rate volatility and relative agricultural prices, 1951-2000.

\begin{tabular}{|c|c|c|c|c|c|c|}
\hline Year & $X_{t}$ & $G D P_{t}$ & $N P C_{t}$ & $\operatorname{TRANS}_{t}$ & $E X C_{t}$ & PRICES $_{t}$ \\
\hline 1951 & 100 & 100 & 100 & 100 & 100 & 100 \\
\hline 1952 & 99 & 102 & 101 & 100 & 74 & 87 \\
\hline 1953 & 94 & 110 & 103 & 100 & 56 & 88 \\
\hline 1954 & 98 & 112 & 104 & 100 & 43 & 93 \\
\hline 1955 & 118 & 120 & 107 & 100 & 34 & 89 \\
\hline 1956 & 130 & 124 & 110 & 101 & 28 & 81 \\
\hline 1957 & 141 & 129 & 111 & 103 & 25 & 82 \\
\hline 1958 & 138 & 129 & 113 & 102 & 23 & 76 \\
\hline 1959 & 154 & 137 & 115 & 102 & 21 & 79 \\
\hline 1960 & 168 & 144 & 111 & 102 & 21 & 79 \\
\hline 1961 & 173 & 151 & 123 & 103 & 20 & 80 \\
\hline 1962 & 183 & 161 & 120 & 103 & 20 & 79 \\
\hline 1963 & 188 & 168 & 120 & 104 & 20 & 84 \\
\hline 1964 & 198 & 180 & 113 & 100 & 20 & 86 \\
\hline 1965 & 206 & 188 & 113 & 103 & 21 & 85 \\
\hline 1966 & 213 & 200 & 103 & 103 & 20 & 85 \\
\hline 1967 & 217 & 207 & 104 & 105 & 30 & 84 \\
\hline 1968 & 227 & 220 & 107 & 106 & 26 & 81 \\
\hline 1969 & 233 & 234 & 106 & 109 & 24 & 82 \\
\hline 1970 & 252 & 244 & 112 & 107 & 22 & 81 \\
\hline 1971 & 258 & 256 & 111 & 106 & 24 & 82 \\
\hline 1972 & 278 & 271 & 119 & 102 & 35 & 83 \\
\hline 1973 & 298 & 290 & 122 & 102 & 30 & 93 \\
\hline 1974 & 287 & 295 & 96 & 105 & 31 & 89 \\
\hline 1975 & 287 & 295 & 98 & 104 & 28 & 82 \\
\hline 1976 & 314 & 315 & 100 & 101 & 33 & 77 \\
\hline 1977 & 325 & 329 & 99 & 105 & 29 & 80 \\
\hline 1978 & 345 & 341 & 108 & 108 & 35 & 74 \\
\hline 1979 & 365 & 354 & 106 & 105 & 34 & 70 \\
\hline 1980 & 382 & 354 & 108 & 109 & 28 & 64 \\
\hline 1981 & 397 & 362 & 97 & 109 & 24 & 63 \\
\hline 1982 & 398 & 366 & 97 & 106 & 50 & 60 \\
\hline 1983 & 401 & 377 & 102 & 99 & 52 & 60 \\
\hline 1984 & 416 & 395 & 93 & 104 & 54 & 62 \\
\hline 1985 & 423 & 409 & 93 & 108 & 63 & 59 \\
\hline 1986 & 435 & 421 & 105 & 107 & 67 & 62 \\
\hline 1987 & 470 & 437 & 114 & 107 & 60 & 60 \\
\hline 1988 & 477 & 455 & 105 & 109 & 73 & 63 \\
\hline 1989 & 491 & 472 & 97 & 111 & 55 & 65 \\
\hline 1990 & 507 & 485 & 97 & 109 & 48 & 65 \\
\hline 1991 & 533 & 490 & 105 & 108 & 37 & 65 \\
\hline 1992 & 575 & 496 & 98 & 111 & 80 & 65 \\
\hline 1993 & 583 & 501 & 102 & 107 & 61 & 64 \\
\hline 1994 & 619 & 512 & 104 & 108 & 52 & 64 \\
\hline 1995 & 634 & 523 & 104 & 110 & 48 & 64 \\
\hline 1996 & 651 & 538 & 95 & 107 & 37 & 64 \\
\hline 1997 & 673 & 556 & 93 & 104 & 33 & 65 \\
\hline 1998 & 688 & 569 & 93 & 109 & 32 & 67 \\
\hline 1999 & 723 & 586 & 97 & 103 & 27 & 64 \\
\hline 2000 & 754 & 609 & 98 & 106 & 31 & 61 \\
\hline
\end{tabular}

$X$ : Agricultural and food exports (in volume terms); GDP: real income; NPC: nominal protection coefficient; TRANS, :

Transport cost; EXC: Exchange rate volatility; PRICES: Real prices of agricultural and food products. 
Source: See statistical appendix

\section{Figures}

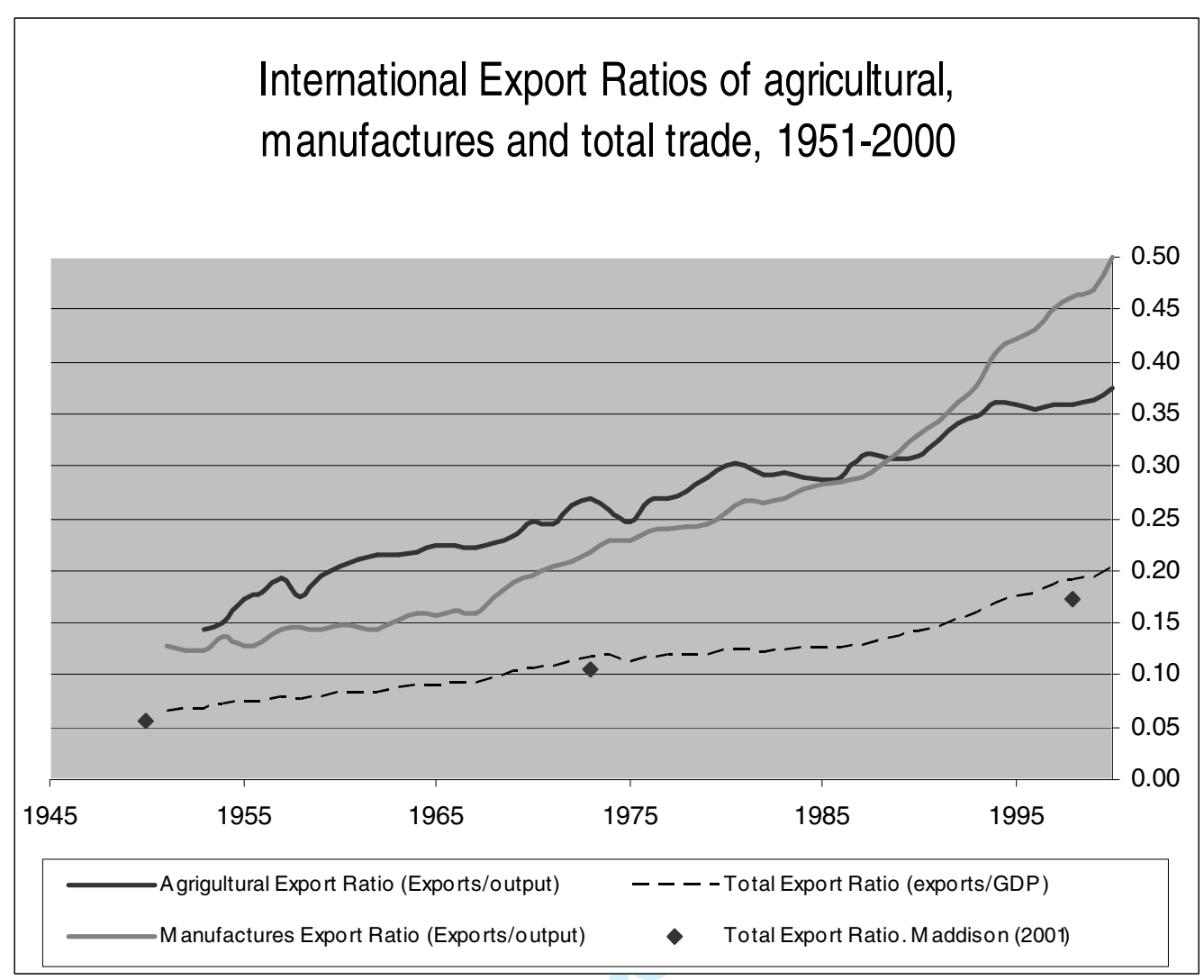

Source: Maddison (2001) and authors' compilation, based on FAO (1947-2000), FAOSTAT (2004), UN Comtrade (2003) and WTO (2003) 


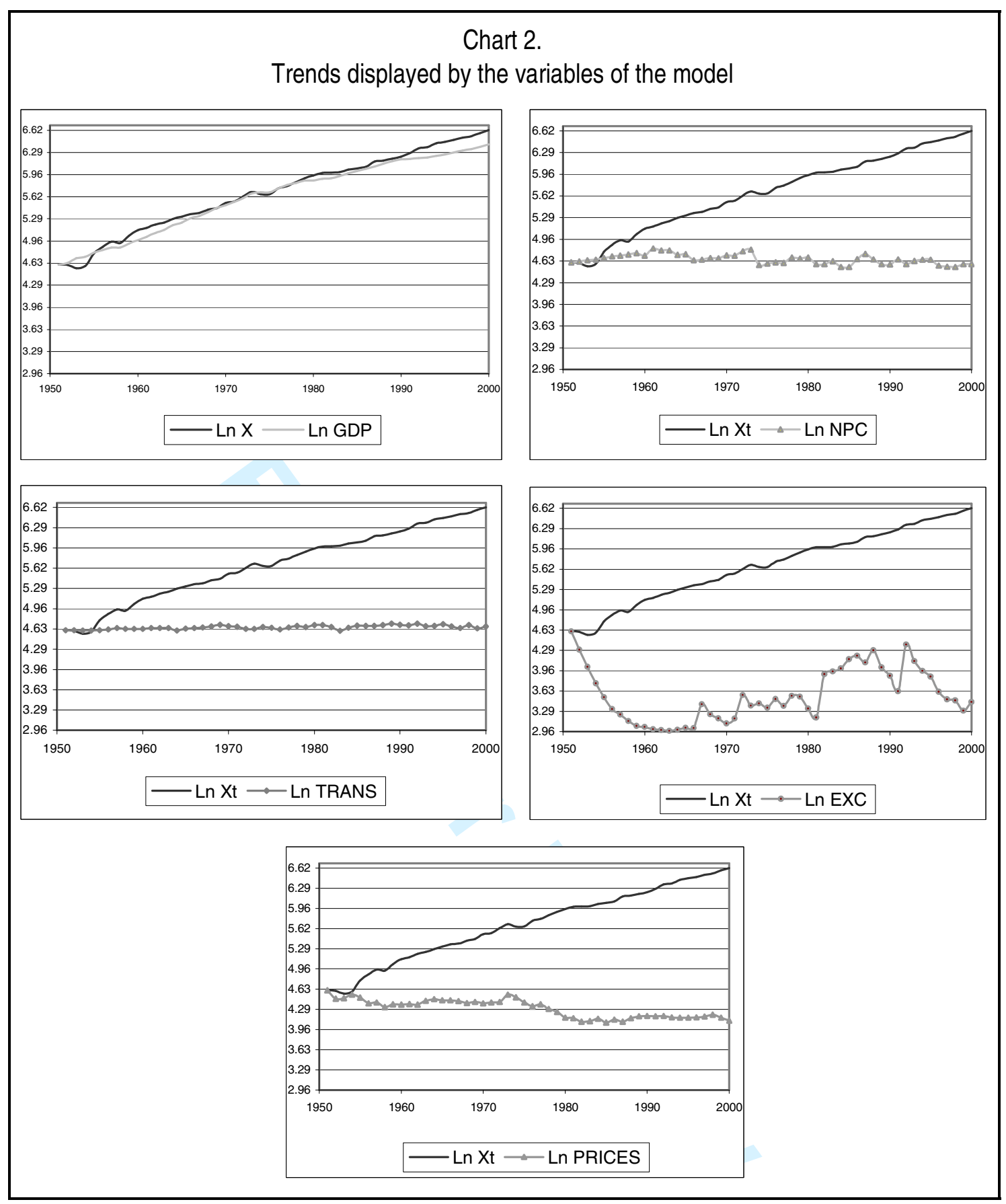

$X$ : Agricultural and food exports (in volume terms); GDP: real income; NPC: nominal protection coefficient; TRANS, :

Transport cost; EXC: Exchange rate volatility; PRICES: Real prices of agricultural and food products 


\section{Appendix: sources and methodology.}

\section{Agricultural trade and prices index}

We reconstructed export (FOB) figures from 1951 to 2000 at current values (in US dollars) for 6 economic regions and 19 product groups. We then aggregated countries and products to obtain two uniform and representative series ${ }^{28}$. The first series runs from 1951 to 1961 , and reflects international trade for a representative sample of 66 countries $^{29}$. The second series (1961-2000) reflects trade for all countries, since the FAO provide estimates when the actual data were unavailable. These series were then linked, on the hypothesis that the countries in the 1951-1961 sample accounted for a similar share of international trade in those years as in 1961-65.

To obtain a series for international agricultural trade by volume, we constructed price indices for the various product groups and employed them to deflate the relevant current price series. We obtained trade data at current prices and volumes for a sample of 66 agricultural trade products ${ }^{30}$, based on the 1961-2000 figures obtained from the FAOSTAT database. We then obtained the present unit prices $(\mathrm{Pt})$ for all these products, enabling us to construct a price index for each product for the period 1961-2000. Subsequently, we integrated these price indices with the United Nations estimates (1987) for the period 1950-1961, which reflect price movements for the same 66 products. Employing the 66 price indices calculated, we constructed weighted indices based on the product share for the 19 product groups. These indices were used to deflate the different series of product groups at current values and subsequently aggregated according to their weight in international trade in 1961, thereby obtaining a synthetic indicator of the evolution of agricultural and food prices. This index was then linked to the price index for total trade utilised by the WTO (2003) and thus an index of real prices for agricultural trade was obtained.

\section{Economic regions}

Africa, Asia, Europe, North and Central America, Oceania, South America and the USSR.

\section{Product groups}

The products included in sections 0 to 4 of the Standard International Trade Classification (SITC Revision 2) were treated as agricultural products. Specifically, these comprise the following 19 subgroups: (00) Live animals, (01) Fresh and prepared meat, (02) Dairy products and eggs, (04) Cereals and processed cereals, (05) Fruit and vegetables, (06) Sugar and honey, (07) Coffee, tea and cocoa, (08)

\footnotetext{
${ }^{28}$ Data for the period 1951-1961 are based on the FAO Trade Yearbooks using the Standard International Trade Classification (SITC Rev.) for that period. Data for the period 1961-2000 are taken from the FAOSTAT database, which utilizes the Standard International Trade Classification (SITC Rev. 2). Both classifications are based on the Brussels Customs Tariff Nomenclature (BCTN). The problems arising due to the differences in these classification systems have been resolved using the UN COMTRADE database (2003) created by the Statistical Division of the United Nations, which includes data from both trade classification systems for the period 1961-2000.

${ }^{29}$ These countries accounted for approximately $80 \%$ of international trade in 1961 (82\% of exports and $78 \%$ of imports).

${ }^{30}$ In 1961 these products accounted for $82 \%$ of international agricultural trade and, despite their share declining at the end of the period, this was still $60 \%$ in 2000.
} 
Animal feeds, (09) Miscellaneous products, (11) Beverages, (12) Tobacco, (21) Leather and hides, (22)

Oil seeds, (232) Natural rubber, (29) Other commodities, (Ex26) Textile fibres, (41) Animal fats, (42)

Fixed vegetable oils, (43) Processed oils

\section{Nominal Protection Coefficient (NPC).}

To measure the degree of protectionism in agricultural markets we calculated an aggregate index of the NPC. This coefficient was defined as follows:

$$
N P C_{i}=\frac{P_{d_{i}}}{P_{b_{i}}}
$$

where $P d i$ are producer prices and $P_{b_{i}}$ border prices. The index was constructed from a representative sample of 13 countries and 20 homogeneous agricultural products ${ }^{31}$. Both the producer and border prices were calculated using FAO Statistical Yearbooks ${ }^{32}$.

To construct an aggregate index of the NPC, we first calculated protection coefficients for each product, weighting the share in the coefficient of each country by its weight in the world trade in each product in 1961. Secondly, to calculate the total NPC of agricultural trade we weighted the share of each product group by its weight in agricultural and food trade in 1961.

\section{Countries}

Australia, Germany, Belgium-Luxembourg, Canada, China, Egypt, France, India, Italy, Japan, Portugal, Spain, the United Kingdom and the United States.

\section{Product groups}

Wheat and wheat flour, Rice, Barley, Maize, Potatoes, Tomatoes, Onions, Apples, Oranges, Bananas, Bovine meat, Pig meat, Poultry meat, Fresh cow's milk, Eggs, Tobacco, Soybeans, Linseed, Cotton, Wool.

\section{Transport costs and CIF/FOB ratios}

To measure the evolution of transport costs of agricultural trade we calculated CIF/FOB ratios representative of bilateral trade. The indicator reflects the part of the product price accounted for by freight and insurance.

$$
C I F / F O B i=\frac{P C I F i}{P_{F O B i}}
$$

where $P C I F i$ is the import price in the country of destination and $P F O B i$ is the export price in the country of origin.

\footnotetext{
${ }^{31}$ These products accounted for approximately $42 \%$ of international trade in 1961 (39\% in 1990).

${ }^{32}$ Producer prices in domestic markets are data from FAO production handbooks (for the period 1950-1973), and the FAOSTAT database (for the period 1990-2004). For the period 1974-1990, the series were provided directly by the FAO Statistical Office, since they are not published. Border prices were calculated using the database compiled from the FAO and FAOSTAT yearbooks, dividing the value of imports/exports by their quantities for each country in the sample.
} 
The index is comprised of a representative sample of bilateral trade flows for 17 product groups (see table below). The CIF/FOB prices were calculated from the trade statistics in the UN COMTRADE database (2003). Firstly, to calculate an aggregate indicator of the CIF/FOB ratio, we performed an analysis of atypical data using the box diagram method, since the national statistics upon which the UN COMTRADE database is based display various incoherencies. Secondly, the CIF/FOB ratio for each product group was calculated using average routes. Lastly, we weighted the share of each product group by its weight in trade in 1968 , in order to obtain an aggregate measurement of the evolution of transport costs for agricultural products.

For the years 1951-1961, we estimated the evolution of this ratio by using the "Liner Shipping Price Index" constructed by Hummels (1999)

\section{SITC Rev.2 product Bilateral trade flows

groups (Importer-Exporter)

011. Meat, fresh, chilled Germany-Argentina, UK-New Zealand, Japan-USA

or frozen

022. Milk and cream

Indonesia-New Zealand, Japan-New Zealand

025. Eggs

Italy-USA, Japan-Australia

041. Wheat including

Japan-Australia, Japan-Canada, Japan-USA UK-Canada, UK-USA, Italy-

spelt and meslin,

Canada, Italy-USA

unmilled

042. Rice

043. Barley, unmilled

Japan-Thailand, Saudi Arabia-Thailand, Saudi Arabia-USA

Saudi Arabia-France, Saudi Arabia-Australia, Germany-Australia,

Germany-Canada, Germany-USA, Italy-Australia, Italy-USA, UK-

Australia, UK-Canada, Japan-Australia, Japan-Canada, Japan-USA

044. Maize corn

Japan-Thailand, Japan-USA, Italy-Argentina, Netherlands-Argentina,

unmilled

Spain-Argentina, Italy-USA, Netherlands-USA, Spain-USA, UK-USA

051. Fruit, fresh and

UK-New Zealand, Germany-Ecuador, Japan-USA, Japan-Ecuador, USA-

nuts excl. oil nuts

Ecuador

054. Vegetables, roots

France-Morocco, France-USA, Germany-Thailand, UK-USA, Japan-USA

$\&$ tubers, fresh or dried

061. Sugar and honey

Japan-Australia, Japan-Philippines, UK-Australia, UK-Mauritius

071. Coffee

Germany-Brazil, Italy-Brazil, France-Brazil, Germany-Colombia,

Netherlands-Colombia, Japan-Colombia, UK-Colombia

072. Cocoa

Netherlands-Ivory Coast, Netherlands-Ghana, Germany-Brazil, Germany-

Ghana, UK-Ghana

074. Tea and mate

UK-Indonesia, UK-Sri Lanka, Netherlands-Kenya, Netherlands-Sri Lanka

081. Feedstuff for

France-Argentina, Italy-Argentina, Netherlands-Argentina, France-Brazil,

animals excl. unmilled

Germany-Brazil, Italy-Brazil, France-USA

cereals 
121. Tobacco, Spain-Brazil, UK-Brazil, Germany-Greece, Germany-Turkey, Germanyunmanufactured USA, Italy-USA, Japan-USA, Netherlands-USA, Spain-USA, UK-USA

221. Oil seeds, oil nuts Netherlands-Argentine, Germany-Brazil, Japan-Brazil, Netherlands-Brazil, and oil kernels Spain-Brazil, Japan-Canada, Germany-USA, Japan-USA, NetherlandsUSA, Spain-USA

231. Crude rubber incl. France-Indonesia, France-Malaysia, France-Thailand, Germany-Malaysia, synthetic \& reclaimed Germany-Singapore, Japan-Indonesia, Japan-Thailand 